Rev. Estud. Ling., Belo Horizonte, v. 28, n. 2, p. 893-915, 2020

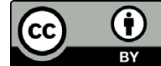

\title{
Multimodal metaphors: from language as a condition to text to the notion of texture as a meaning-making semiotic resource
}

\section{Metáforas multimodais: da língua como condição para texto à noção de textura como recurso semiótico para produção de sentidos}

\section{Clarice Gualberto}

Universidade Federal de Minas Gerais (UFMG), Belo Horizonte, Minas Gerais / Brazil clagualberto@gmail.com

http://orcid.org/0000-0003-2759-7444

Záira Bomfante dos Santos

Universidade Federal do Espírito Santo (UFES/CEUNES), São Mateus, Espírito Santo / Brazil

zbomfante@gmail.com

http://orcid.org/0000-0002-6162-8489

\section{Ana Clara Meira}

Universidade Federal de Minas Gerais (UFMG), Belo Horizonte, Minas Gerais/ Brazil Instituto Federal do Norte de Minas Gerais (IFNMG), Salinas, Minas Gerais / Brazil anaclara.gmeira@gmail.com

http://orcid.org/0000-0003-0429-7211

\begin{abstract}
In this paper, we attempt to provide some ways of thinking about text, relating it to the concept of metaphors, multimodality and texture. Our aim is to develop new insights in meaning making and communication more generally, by bringing examples of memes; a relatively new genre, often seen on social media posts. To do so, we discuss the notion of text (HALLIDAY; HASAN, 2002; BEAUGRANDE, 1997; KRESS, 2010 ) and then, we discuss texture as a semiotic resource for the production of texts and its metaphors (DJONOV; VAN LEEUWEN, 2011). To exemplify some concepts
\end{abstract}


and categories, we explore memes, seeking to understand their constitution as well as their qualities and potential meanings of visual textures deployed in the text to make meaning material through multimodal metaphors.

Keywords: text; texture; social semiotics; multimodal metaphors.

Resumo: Neste artigo, pretendemos propor algumas maneiras para se pensar a noção de texto, relacionando-a aos conceitos de metáfora, multimodalidade e textura. Nosso objetivo é desenvolver novos insights a respeito da produção de sentido e da comunicação de forma geral. Como exemplo, trazemos memes com o bordão " $E$ ' verdade esse bilete”. Como esse gênero é relativamente novo e frequentemente visto em posts nas redes sociais, discutimos a noção de texto (HALLIDAY; HASAN, 2002; BEAUGRANDE, 1997; KRESS, 2010) e de textura como um recurso semiótico para a produção de textos e suas metáforas (DJONOV; VAN LEEUWEN, 2011). Para exemplificar algumas noções e categorias, exploramos os memes, buscando compreender como eles se constituem, assim como suas qualidades e seus possíveis sentidos de texturas visuais utilizadas para produção de metáforas multimodais.

Palavras-chave: texto; textura; semiótica social; metáforas multimodais.

Submitted on December $13^{\text {th }}, 2019$

Accepted on January $31^{\text {st }}, 2020$

\section{The multimodal semiotic world: an introduction}

This paper intends to expand the traditional notion of text commonly tied to verbal mode (language). To achieve such purpose, we relate three important concepts: multimodality, texture and metaphor, exemplifying some categories and notions we present through a brief analysis of memes.

The main argument which underpins our study assumes that multimodality - the presence of more than one mode - is an inherent aspect of all texts. Therefore, there is no such a thing as "monomodal texts". Even a text that seems to be "only verbal" (a formal document, for example), presents modes other than writing - it has color, a certain font-type (typography) and it is organized / displayed in a specific way (layout). With that being said, the expression "multimodal text" becomes reductant. In one hand, its use might be necessary to emphasize the presence of more than one mode in all texts. In the other hand, it 
could imply that some texts are multimodal and others are not. So it is important to clarify that multimodality is a basic aspect of every single text we produce.

Another necessary clarification on multimodality is that it does not depend on the mix of verbal and visual to "turn" a text into a multimodal one. Texts may or not present the verbal or the imagery mode.

According to Halliday (1994), no one escapes language: "Neither of these exists without the other: there can be no social man without language, and no language without social man" (p. 12). Therefore, human existence cannot be mute. According to Freire (1993), dwelling is to communicate the world. Such pronunciation of the world occurs in dialogue with all modes, based on social and cultural work. Similarly, Bakhtin (2006b) argues that our existence is intrinsically related to dialogues in which we take part. In this dialogue, one participates with all his/her body: with eyes, lips, hands, soul, ears, head etc. Thus, the world we communicate reveals our existence; our place become material and concrete, and that is what we call text.

The term text holds a diversity of conceptions, which is a natural process - since it shows the theoretical renewal in a ceaseless development of linguistic studies. The notion of text has assumed prominence as a very comprehensive concept for many types of work such as novels, books, paintings, advertisements, electronic media, films and drama performances (COLLOW, 2005). The benefits of such textual approach, according to Kress (2002), are many, but at the same time, any approach to a field will privilege, by necessity, one way of thinking at the expense of other possibilities. Language, written or spoken, usually tends to be the focus of linguistic research. However, in this paper, we start from a broader perspective, drawing attention to communication in all its forms and modes; that is why our approach is multimodal. Essentially, multimodality is not a theory, but a domain of study. In our case, we look at multimodality through social semiotic lens (HODGE; KRESS, 1988; KRESS, 2010). Roughly speaking, this theory deals with action and interaction and meaning-making processes. Therefore, our main goal here is to discuss how the material resources for meaning production - which are diverse and are not limited to the use of verbal modes (speech and writing) - configure new textures for texts.

When we use terms such as material and texture, we refer to contributions of Kress (2015), by relating them to the engagement of 
individuals with texts through human sensory aspects (e.g. touch or visual experiences). Meaning-making processes, in multiple articulations through material resources, have been affecting theories on speech and writing. An example of this is the study carried out by Cope and Kalantzis (2009), in which they state that language itself is invariably multimodal; writing is visually drawn, and orality has fundamentally important audio qualities.

Such argument brings to the fore the notion of interest, one fundamental concept of Social Semiotics, which deals with the motivations involved in meaning-making processes. Therefore, we seek to discuss notions of text and texture as motivated (non-arbitrary). To do so, we begin by relating language to text, and questioning their interdependent relation as conditions for communication. Likewise, we deal with the notion of texture as semiotic resource and some potential meanings it brings to visual and tactile surfaces. After that, we present examples of digital texts called "memes", to exemplify semiotic modes, resources, the relation between them and their arrangement throughout the text. We also look at potential meanings produced by those texts, through the interplay of metaphors, visual and auditory modes expanding the traditional semiotic landscape.

\section{The notion of text}

Our comprehension of text is mainly constituted by ideas from Beaugrande (1997), Cope and Kalantzis (2009), Halliday and Hasan (2002), Kress and van Leeuwen (2001) and Kress (2010). Overall, these studies see text as a communicative event in which cultural, social and cognitive actions converge, weaving through a mesh of motivated semiotic threads, enabling new designs, forms of interaction and representation in a communicative context. In other words, senses are constructed in increasingly multimodal forms - in which representational modes interact with spatial, tactile, gestural, auditory, and oral patterns of meaning.

When we focus on the diversity of cultural practices, we notice that it remains on a traditional notion of textual literacy, the concept of text still privileges language-based understandings. A social semiotic account on the definition of text considers images, movies, art exhibitions, music etc. as texts. Therefore, they can (and should) be analyzed with 
the same consistency and complexity as traditional texts - where the verbal prevails. The study of target-audience project on those texts as well as their structure and grammar constitute means of understanding and critiquing them. We believe that there is a wide range of benefits and possibilities in using this paradigm.

When we turn to the etymology of the word text, we see it is derived from the Latin verb texo, which means interweave, weave, plait. Such definitions lead us to understand the term text as a unit whose parts are woven. Therefore, it is relevant to understand the intertwining of these parts and arrangements. An attempt to do that through multimodal sociosemiotic lens, implies that culture is understood as a set of semiotic systems, systems of meanings that are interrelated.

In a broad sense, Halliday and Hasan (2002, p. 4) argue that "there are many other ways of producing meaning in a culture that are outside the domain of language", pointing to the notion of multimodality, the authors bring a simple, yet important definition about text: "We can define text, in the simplest way perhaps, by saying that it is language that is functional. By functional, we simply mean language that is doing some job in some context [...]" (HALLIDAY; HASAN, 2002, p. 10).

As we can see, the authors define text as a metafunctional construct, that is, language is determined by the function it serves to, whether to interact with (interpersonal function), represent (ideational function) or organize (textual function) information. Essentially, text is a semantic artefact, a social exchange of meanings, of interaction between speakers. Thus, it is taken as the main object of investigation and conceived as a social semiotic product which reveals interactional activities.

If we turn to the field of textual linguistics, Marcuschi (2008, p. 87) makes a crucial statement: "paraphrasing Kant, in a somewhat clumsy expression, that the language without context is empty and the context without language is blind". ${ }^{1}$ The linguist points out that one text cannot be produced or understood if language alone is considered. The concept of text includes notions of culture and mental processing as constitutively interconnected instances. Thus, we see an intrinsic relationship between text and context.

\footnotetext{
${ }^{1}$ Our translation of: "Parafraseando Kant, numa expressão um tanto desajeitada, que a língua sem contexto é vazia e o contexto sem a língua é cego" (MARCUSCHI, 2008, p. 87).
} 
Looking at contributions of Beaugrande (1997), we notice the author does not define text as a simple sum of sentences and words. Text is seen as "a system of connections between various elements: sounds, words, meanings, speech participants, actions in a plane. Since these elements clearly belong to different types, the text must be a multisystem composed of multiple interactive systems" (BEAUGRANDE, 1997, p. 16).

It is important to highlight the impact of cultural technologies involved in the production of meanings and the means of disseminating meanings as text. By technology, we mean a range of cultural resources made by society that are involved in the production of meaning material, modeling effects on the meanings produced and that are involved in the display and distribution of texts. In sum, technology is understood as (i) "technology of representation": modes, used in the production of material meanings; (ii) "technology of production": material resources such as a pen, paper and electronics, digital and non-digital and non-material semiotic resources such as genres, frames, cohesive devices, speeches; (iii) "technology for the distribution or dissemination of meanings as messages" (KRESS, 2015, p. 52).

Technology in the so called "era of information" enables an ecology (KRESS, 2015) of meanings and communication, enables the participation of social individuals in life, who dialogue with the world through texts in a sociocultural context. Therefore, our social practices are always multimodal; we always employ more than one mode when we make meaning. Voice has intonation, silence, rhythm, pace and may also have words, gesture, facial expression and so on. This perspective allows us to reconsider the role of language as the main semiotic mode in the production of meanings, solely capable of expressing all aspects of human life. A social semiotic perspective not only challenges such centrality, but also places other modes of communication at same level of importance traditionally attributed to language.

It is necessary to look at and understand some effects of the ecology of meaning as well as communication and consider that these changes will be accompanied by a broad reconfiguration of the place of language in the social / cultural / semiotic and epistemological world. By anchoring ourselves in a conception of living tongue, whose vitality is through use, we assume the agency of the subjects. In this process of agency, the meaning maker has intentions, values, desires, fears, etc. which are considered when acting by selecting semiotic modes that meet purposes of communication and representation. 
Therefore, given the plurality of modes and the diversity of audience (readers), in thinking about the role of the producer (designer), we shift the focus: from a competent performance to the production of adequate (apt) design that, which demands choices that will configure the aesthetic dimension of the text and, consequently, its texture. Thus, this dimension or the aesthetic taste of the meaning maker (designer) is not divorced from the social and political forces of the situational and cultural context in which it is inserted.

All meaning-making processes are complex; they involve a wide range of connections among interests, backgrounds and experiences. In this complexity, modes are used together, constituting a set of modes $-\mathrm{a}$ multimodal ensemble. The notion of sign becomes a fundamental element, since it is the core unit considered by semiotic studies. Under a social semiotic perspective, signs are always motivated (and not arbitrary) and they are organized as sign-complexes - a complex of coherent elements. A complex of signs will then foster another sign-complex made by whoever interacts with the text, establishing an interweaving, a cadence between various signs used in a social interaction, in a multimodal ensemble.

Signs are produced in specific environments, intended for an audience and with specific purposes based on interests of their producer, available semiotic resources and awareness of the social environment configuration. Furthermore, Kress (2010) relates both social and individual aspects by stating that:

If the notion of 'interest' is extended to the making of signs by the fully acculturated, fully socialized individual, we will have to take into consideration the individual's social and cultural histories, and her or his present social positioning in the whole complex of social structures which make up an individual's relationship to an object or event, acting out of that social complex particular moment. (KRESS, 2010, p. 174)

In a sociosemiotic perspective, signs are metaphors because "all signs are formed in a metaphoric process" (KRESS, 1993, p. 174). When producing a sign, we associate forms and meanings through analogy, which is the essence of metaphors: "Signs are the result of metaphoric processes in which analogy is the principle by which they are formed. Analogy is a process of comparison, or classification: $\mathrm{x}$ is like $\mathrm{y}$ (in criterial ways)" (KRESS, 1997, p. 11). This can be clearly seen in Figures 3 and 4 (that will be further analyzed) where people use modes 
of writing and typography in a certain way that texts may "look like" or "sound like" a child created them. The grammar and the visual aspects of writing were created through a metaphorical process of comparison.

According to Machin (2007), visual communication is rich in similar kinds of associations, in other words, available semiotic resources have potential to make meaning through metaphorical association, that is, experiential associations. For van Leeuwen (2005, p. 30), the essence of metaphor is transference. There is transference from one domain to another due to some perceived association. In other words, an association can be transported from the domain of objects in the real world to the visual elements on the page or screen.

Lakoff and Johnson (1980, p. 47) see such transport of meaning from one domain to another as a fundamental feature of the way that humans organize their experiences. The authors bring some examples of ideas. For them, we often talk about ideas through the metaphor of food such as 'chew over this idea' or 'I can't swallow what you are saying' or 'I need time to digest what you have said'. As these metaphors become so established, we cease to notice them as metaphors at all. However, such metaphor, and the meanings that they transport, according Machin (2007), are central to meaning creating in different communicative modes. Machin states that we also transport meanings of up and down into music. Melodies that go up in tone to be increasing in energy while those that go down are thought to be decreasing in energy. High and low intensities also influence the meaning of colors. The ones with a high degree of saturation are associated with high energy and intensity whereas weak colors are associated with either lower energy or with greater moderation.

Although we recognize the importance of the work Lakoff and Johnson (1980), in this work we focus how meaning are built multimodality, how metaphoric process of signs are motivated and articulated. Since all signs are metaphors, it is important to understand how the material and nonmaterial aspects of the sign are articulated in the production of meanings. From non-material or conceptual aspects, they are understood as categories to establish entities, actions, relations, genres, frames, in other words, the means for producing cohesion and forms of coherence.

When we understand the global meaning of text, we can ask ourselves: How do we understand the role and partiality of each mode in semiotic work? At the macro level, is it possible to look at the whole and see the parts? Or at the micro level, is it possible to look at the parts of 
each mode and perceive the whole? To initiate an attempt of responding to such questions, we seek to understand, in the following section, texture as a semiotic resource that enables visual perception, tactile etc. in an integrated way as well as exploring the materialization of meaning making in different media, since we take the text as a multimodal set.

\subsection{The notion of texture as a semiotic resource for making multimodal metaphors}

In the words of Djonov and van Leeuwen (2011, p. 541), the term texture is originally linked to "the art of weaving and the qualities of woven materials, but gradually expanded to encompass the tactile, material quality of objects generally and the synesthetic interaction of tactile, visual and aural features". Given the unfolding of such term, it is often used to describe the quality of modes and their resources, within a multimodal ensemble, such as the texture of sound (quality of tone such as tension, volume, roughness, vibrato), and, applied to the image, it suggests the illusion of tangibility. Under a social semiotic approach, texture is, therefore, a semiotic resource with tactile, visual, and auditory manifestations playing an increasingly important role in the semiotic scenery.

Despite the growing importance of texture in a range of semiotic practices, it has not received proper academic attention. Kress and van Leeuwen (2001) argue that such fact is due to a tendency of linguistic, literary and semiotic studies to privilege the design of texts and ignore the contribution of their production, communicative use of media and material resources to produce meanings. From the authors' perspective, texture points to two types of potential meanings: provenance and experiential meanings.

Provenance is linked to the origin of the signifier and the values attributed to it in each context. Djonov and van Leeuwen (2011) situate the denim fabric, pointing out that at first it was used for the production of garments such as heavy trousers for miners, slaves etc., and in another context later the blue jeans meant in the imagination of American cowboys a preference for designating functionality, simplicity, and a choice of equality against class society, meaning a break with traditional bourgeois dress and the values associated with it. Soon, jeans became a symbol a metaphor of sophistication, refinement, elegance.

In many other contexts we can see what meanings are being attributed to material resources such as fashion, architecture, cooking 
and so on due to cultural, historical and social aspects, among others. Depending on the context of interpretation, these meanings attributed to the quality and origin of the material may have negative and positive interpretations. For authors, provenance often assigns values to textures, however, it is linked to a type of general knowledge that derives from mass media rather than formal education. In this sense, it is complex to systematize, however it continues to be used by advertisers, designers, popular writers, etc.

Considering experiential texture meanings not only involves qualities that will be allowed for a given texture in relation to others, but also implies their link between identifying the quality of the material and associating it with one or more different senses. This movement enables the understanding of synesthesia that can be materially realized and recognized in different media (KRESS; VAN LEEUWEN, 2001). In this paper, we draw our attention to both tactile and visual textures. The tactile texture or tactile surface structure can be felt as we move our fingers lightly over the surface of an object. Tactile texture involves shape, volume, size, weight, but these three-dimensional aspects translate less easily into a two-dimensional visual representation and are less relevant to our interest in computer graphics.

Each form of texture has a value for each material quality. Djonov and van Leeuwen (2011) identified six primary tactile qualities:

FIGURE 1 - System network of primary qualities of tactile surface texture

\begin{tabular}{|c|l|l|}
\hline \multirow{4}{*}{ Tactile-surface-texture } & Liquidity & Wet / Dry \\
\cline { 2 - 3 } & Viscosity & Non- sticky / Sticky \\
\cline { 2 - 3 } & Temperature & Hot / Cold \\
\cline { 2 - 3 } & Relief & Flat / Relief \\
\cline { 2 - 3 } & Density & Dense / Sparse \\
\cline { 2 - 3 } & Rigidity & Soft / Hard \\
\hline
\end{tabular}

Source: Djonov and van Leeuwen (2011, p.549).

The identification of these qualities implies the production of metaphorical experiential meanings in certain contexts. 
$\checkmark \quad$ Liquidity - every surface texture will have a value ranging from wet to dry, can be associated with the idea of water, life, human skin and so on. And negatively can mean rot, ruin etc.

$\checkmark \quad$ Viscosity - may have negative associations by the term itself or by associations with contamination, such as a bathroom or a dirty kitchen. However, it may suggest the idea of safety, support, help as in ergonomic design of bicycle handlebars or mouse pads.

$\checkmark \quad$ Temperature - are rich sources of metaphors, cold can mean lack of affection while warm conveys the idea of warm, affectionate, intimacy etc.

$\checkmark \quad$ Reliefs - relief meanings will depend on many factors, flat surfaces may indicate lack of engagement, however on the plus side may indicate softness, suggesting youth, something new and purity etc.

$\checkmark$ Density - can evoke the idea of solidity, resilience, high quality due to abundance whereas low density (drainage) can evoke the idea of economy, poor durability, brittle etc.

$\checkmark \quad$ Rigidity - rich source of experiential metaphor. Softness may indicate sensitive, submissive, accommodating while firmness / rigidity may indicate strong, durable, stable or severe.

Regarding the visual texture, in general, it can be presented visually through specific techniques for the use of colors, lines, shapes. Visually representable tactile surface texture qualities can be categorized into material, association and symbolic qualities. Material qualities can be described without reference to specific objects: Relief - achieved by the absence or presence of curves, uneven lines, color variations; Density - can be presented by distributing lines, colors, color variation and saturation; Rough or smooth - made by gradations of color use and line distribution; Consistency - created by the homogeneity or heterogeneity of the use of colors, lines and shapes.

As far as associative qualities are concerned, they can be described as specific aspects of objects. They include liquidity, viscosity and rigidity and, in some cases, temperature. For instance, the softness of velvet can only be suggested through representations of objects made by velvet such as dress, curtains etc. Visual representations of dry or damp surfaces are also suggested by objects such as cracked soil, an old dry tree or liquid in a glass of water in case of moisture. In the case of the visual representation of an ice cream, regardless of color, it would 
evoke the idea of something cold, icy and project on the reader, in intense heat conditions, the synesthetic effect of freshness, relief. In short, the material qualities of this group are strongly linked to the objects used for representation, blurring the boundaries between provenance and potential experiential meanings. As an example, Djonov and van Leeuwen (2011) situate velvet as a delicate fabric that is likely to evoke luxury, ostentation, while a more durable jean fabric can evoke practicality.

As for symbolic qualities, they have a conventional representation and evoking the meanings that tactile qualities suggest, such as the use of warm or cold colors to represent cold or warm surfaces. However, the authors state that some visual textures have no equivalent tactile texture as they include intrinsic visual patterns to the object; patterns that reflect an object's interaction with the environment such as transparency, lightness, and abstract patterns. Transparency, for example, can be achieved by varying the distribution and color values, which may or may not represent tactile qualities of liquidity and density. If it does not represent tactile qualities, its potential meaning will be similar to others.

In short, while some texture qualities may apply to different media and being described as synesthetic, others may be purely visual or purely tactile. The purely tactile qualities are inaccessible to the visual. However, the qualities that are shared can be used in software application and evoking tactile sensations and associated meanings in different extensions. In general, we have studied the visual, auditory, tactile texture in isolation, looking at the small parts. In this sense, we explore the design of the meme genre seeking to understand which textures have been articulated; which qualities and aspects of potential tactile or visual texture meanings have been used. Thus, the notion of texture (provenance and experiential meanings) as a semiotic resource to make meaning material evokes the multimodal metaphors.

\section{Meme as a genre}

We believe a few examples will provide great contributions to our discussion on the notions of text, texture and multimodal metaphors. We chose memes ${ }^{2}$ because they represent a current genre that has become quite popular. Therefore, we intend to analyze them, focusing on aspects

\footnotetext{
${ }^{2}$ A digital text which usually combines an image with one or two phrases that are often ironic or sarcastic.
} 
of the materialization of meaning, considering the various multimodal aspects that emerge from this genre.

For Marcuschi (2008, p. 155), "textual genres are texts that we find in our daily life and present characteristic socio-communicative patterns defined by functional compositions, enunciative objectives [...]". ${ }^{3}$ Thus, in this paper we consider the meme as a genre, because it has a prototypical textual structure: the language is usually mixed, presenting an image that is noteworthy and is associated with verbal elements which usually appear in the lower or upper margin with the foreground image, characterized as a multimodal text. In addition, they have a typical function: to present content that can be humorous, ironic or critical, which spreads quickly on the web. Thus, by presenting a structure and a function, we consider it pertinent to understand the meme as a genre. Therefore, it is defined as being made up of multimodal characteristics with the tendency to replicate it quickly and to transform it at the same pace.

Moreover, analyzing the meme genre shows that the language is not only constituted by structure; therefore

every language carries within itself a worldview [...] beyond its formal aspect. Studying only the formal aspect [...] detaches the student from the intrasubjective, intersubjective and social character of language (BRASIL, 2000, p. 6-7). ${ }^{4}$

The meme genre also plays an important role today, as just as diverse information is quickly shared across countless media, it also spreads significantly. Another aspect that we emphasize is the prominence received by the image in the meme, which reveals a relationship of this kind with social demands, because "In an attempt to explain intense emotions, statements on numerous subjects, feelings, and political, social, economic, and affective positions, memes emerge as representations of a contemporary culture with fluid implications, and spread rapidly" (CANI, 2019, p. 252).

\footnotetext{
${ }^{3}$ Our translation of: "os gêneros textuais são textos que encontramos em nossa vida diária e que apresentam padrões sociocomunicativos característicos definidos por composições funcionais, objetivos enunciativos [...]” (MARCUSCHI, 2008, p. 155). ${ }^{4}$ Our translation of: "toda linguagem carrega dentro de si uma visão de mundo prenha de significados que vão além do aspecto formal. $\mathrm{O}$ estudo apenas do aspecto formal [...] desvincula o aluno do caráter intrasubjetivo, intersubjetivo e social da linguagem" (BRASIL, 2000, p. 6-7).
} 
In this sense, the meme genre is associated with the aspirations of today's society to transmit a message through multimodal resources, using a small, objective and viralizing verbal language. In this perspective, the meme connects to this new culture called cyberculture, conceptualized by Lévy (1999) and further explained by Bruno (2019, p. 119) "understood as the culture of digital networks, it is plural and plastic, as it houses multiple sociocultural movements in cyberspace". Therefore, memes allow us to identify the variety of meanings that are made through communication and how multimodal metaphors manifest themselves in contemporary times.

This genre also reaffirms an understanding of the complexity of language, since

The true substance of language is not constituted by an abstract system of linguistic forms, neither by the isolated monological utterance, nor by the psychophysiological act of its production, but by the social phenomenon of verbal interaction, carried out through utterance or utterance. Verbal interaction thus constitutes the fundamental reality of language (BAKHTIN, 2006a, p. 125).

Accordingly, when we observe the construction of meanings in modernity, we note that digital technologies contribute to the emergence of new genres permeated by multimodality, which collaborate in the resignification of the role of receiver and producer of texts, not inserting them in isolated concepts and opposites, but from an integration perspective where the recipient of the text can also play the role of producer and vice versa.

\section{Meme genre analysis: mapping potential meanings}

For genre analysis, we chose memes that had a significant repercussion in 2018 and demonstrated how constructed meanings are directly related to cultural, social and ideological patterns. In addition, they exemplify Halliday and Hasan's (2002) notion of text and explain how texture as a semiotic resource contributes to the perception of multimodal metaphors.

\footnotetext{
${ }^{5}$ Our translation of: "a verdadeira substância da língua não é constituída por um sistema abstrato de formas lingüísticas, nem pela enunciação monológica isolada, nem pelo ato psicofisiológico de sua produção, mas pelo fenômeno social da interação verbal, realizada através da enunciação ou das enunciações. A interação verbal constitui assim a realidade fundamental da língua" (BAKHTIN, 2006b, p. 125).
} 
In 2018, a 5-year-old boy from the interior of São Paulo handed a note to his mother, informing her that there would be no class due to a possible holiday. In addition, the boy attributed the authorship of the note to his teacher, as shown in the following image:

FIGURE 2 - Meme $\# 1^{6}$

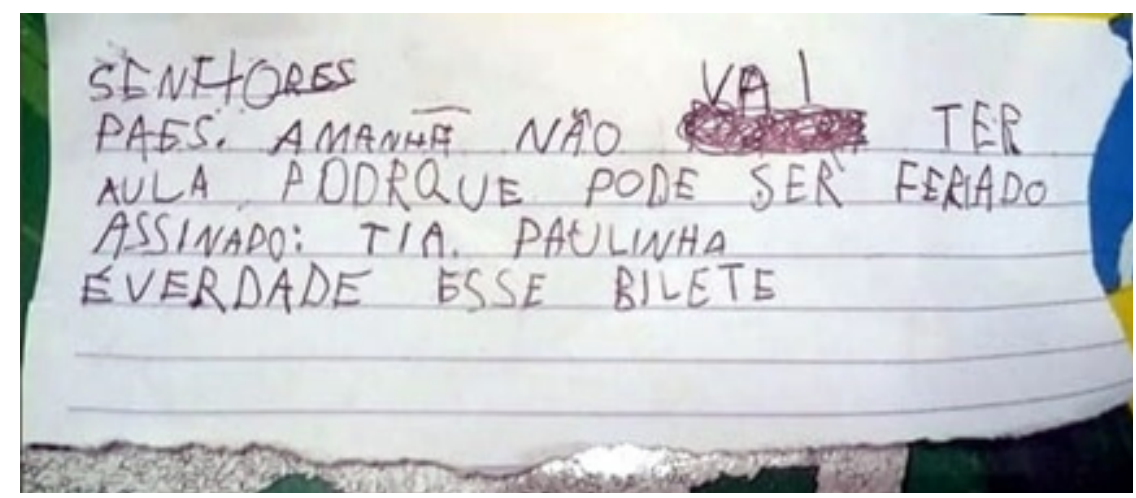

We highlight the fact that the boy was able to produce a note following basic characteristics of this genre; however, when committing inadequacies regarding the standard norm (such as: paes, podrque, bilete); erasures (which would not be typical on a teacher's note); handing out a piece of paper that is detached in any way with uneven letters - which may characterize a child's handwriting - makes it clear to the mother who is the real author of the note.

By associating the notion of texture of Kress and van Leeuwen (2001) with this note, we understand the potential meanings mentioned by the authors (provenance and experiential meanings). About provenance, we realize that the origin is not a note written by a teacher or whose origin refers to an educational institution. The characteristics previously listed, such as irregular writing, orthographic inadequacies and the paper, reinforce that the sender of this message was a child.

As for the experiential meanings, on the piece of paper, we realize that there is no linearity in the margins, there are curves in the lower margin, which reveals a visual texture that can be associated with the tactile in which the relief aspect is highlighted by the irregularities.

\footnotetext{
${ }^{6}$ Available at: https://segredosdomundo.r7.com/e-verdade-esse-bilhete-um-dosmaiores-memes-de-2018/. Access on: Sept. $7^{\text {th }}, 2019$.
} 
Thus, these textures evoke the certainty that the note was not written by the teacher, who, even if she had written it in handwriting, probably she would have been more careful in selecting and cutting out the paper. Still regarding the experiential meanings, we emphasize once again the asymmetry and variation of the letter size, which reveals a visual texture through the relief (presence of irregularities) and the consistency (heterogeneity in the size of the letters), reaffirming the sense that the note was not written by aunt Paulinha.

From this note, several memes were viralized on the internet with different themes, but always with the catchphrase: 'this note is true'. Therefore, we will analyze two memes constructed based on this context, one with a playful content and another that addresses a controversial issue of today. Next, we will see how the notions of texture manifest in the meme that there is bias towards entertainment and distraction, whose protagonist is a dog.

FIGURE 3 - Meme $\# 2^{7}$

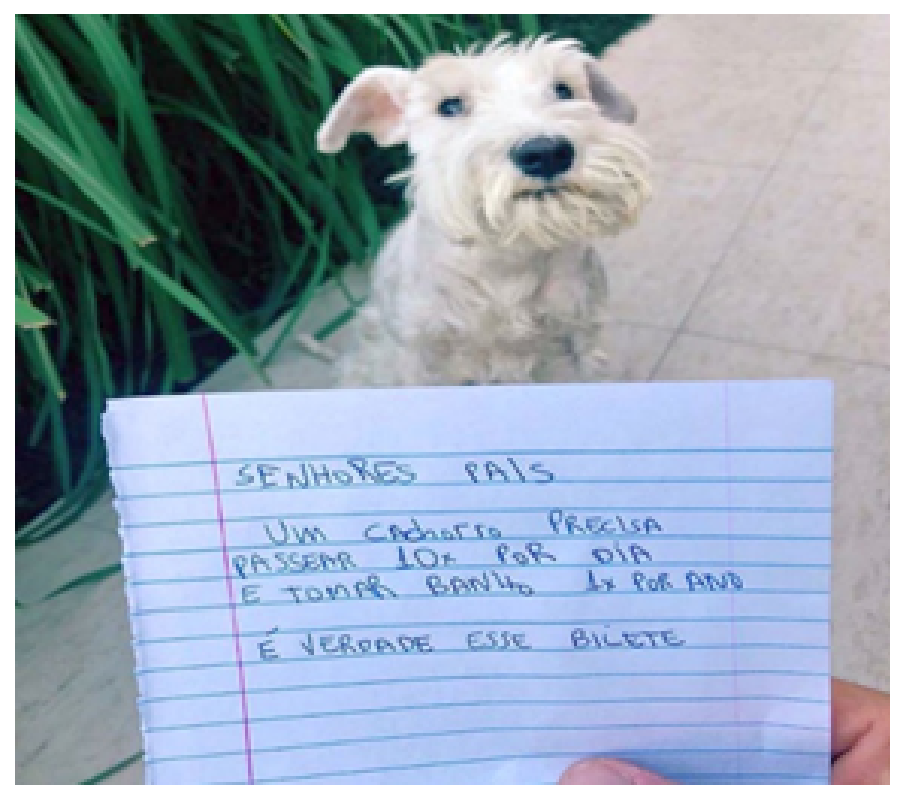

\footnotetext{
${ }^{7}$ Available at: https://www.tribunapr.com.br/noticias/brasil/show-de-memes-depoisdo-menino-do-bilete-os-pets-mandam-seus-recados-para-seus-donos/. Access on: Oct. $11^{\text {th }}, 2019$.
} 
In this meme, concerning experiential meanings we note that, regarding the tactile textures, we can highlight, in terms of liquidity, the dry quality, because the moisture characteristic does not dominate the environment. Thus, on the floor, there is no water, mud, or dirt, which leads to the idea that the owner cares about hygiene, demonstrating not only cleanliness, but also affection and zeal. In addition, this care also manifests itself in the dog's hair (white and clean), which expresses a concern for the welfare of the pet. We also highlight that when it comes to rigidity, the dog's hair allows to associate visual textures with tactile, because this specific aspect conveys softness.

Regarding the ticket, it follows similar characteristics from its origin: similar structure with the completion of the sentence: "this note is true". There are some differences from the original text, as the meme in question has no signature, no erasures, and although it is written on a piece of paper, it does not have as many irregularities in the cut as the paper chosen by the boy on the original note. Regarding the linguistic aspect in this meme, the only orthographic inadequacy is the word bilete. In relation to the potential meanings, in the provenance aspect, the text suggests that the authorship belongs to an adult, probably a veterinarian, indicating the care that the parents (in this case the dog owners) should take with the pet.

However, the visual textures that emerge from this note in the item relief reveal the idea of authorship. It is noteworthy that the text was written in a simple notebook paper, detached without scissors, due to the irregularities presented in the left margin, which denounce that the vet was not the author of the ticket. Still in the relief aspect, the irregularities are also manifested in the spelling of the letter. The content also shows that the vet is not the real author, as he would not make a recommendation to bathe only once a year and, on the other hand, to walk ten times a day. Thus, as to the provenance, the intention is to convey the idea that the author of the note would be the dog, which is reaffirmed by the dog's pitying gaze, as if he wished the owner to follow exactly what is written on the note. On the other hand, as the dog has no skills to write a note, we know that its authorship refers to its owner, as a way to generate entertainment in relation to the statement: "This note is true".

Visual textures of the image as a whole, in relation to consistency, reveal a uniformity of colors, as there is a dominance of lighter and neutral tones, allowing to infer multimodal metaphors that evoke an environment 
of tranquility, harmony, which can be associated with a happy home. The notions of texture amalgamate, building a web of meanings that allows us to understand how the internet plays an important role in society. From this perspective, a note from a boy has such a significant repercussion that people reproduce scenarios, texts that can become memes and generate various social, political, and cultural impacts, among others; tied to a particular context.

Then we will look at another meme with the sentence: É verdade esse bilete:

FIGURE 4 - Meme $\# 3^{8}$

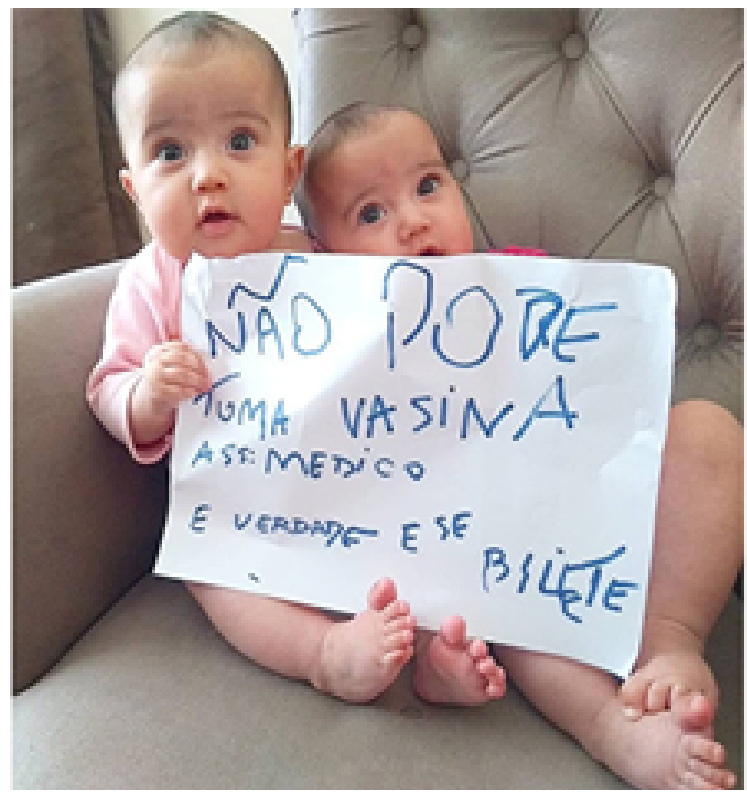

In Figure 4, the visual mode presents babies sitting on a couch and holding a sheet of paper. Regarding the verbal mode, we notice inadequacies in relation to the standard variety, such as: toma, vasina, doctor, e, ese, bilete. Thus, on the provenance, the note indicates at the signature that this information was given by a doctor. However, looking at the visual textures evoked by the meme, we highlight the irregularities

${ }^{8}$ Available at: http://www.museudememes.com.br/sermons/e-verdade-esse-bilete/. Access on: Oct. $11^{\text {th }}, 2019$. 
of the letters in the relief aspect, which vary in size and thus reveal a heterogeneity in the size of the letters (consistency), reaffirming that the text was not written by a doctor. Moreover, still on the provenance, it is not common for doctors to write notes, but a prescription which has a prototype structure with the name of the patient, prescription, date and signature of the doctor. Thus, the evoked textures allow us to infer that this health professional is not the author of the note, nor the babies, since they cannot yet write a text. The likely authors would be the parents of the babies who appropriated the statement: This note is true, through the discursive context, to arouse criticism about the act of not vaccinating.

As for the experiential meanings, we also mentioned an association between tactile and visual textures, since the presence of babies evokes, in the rigidity aspect, the characteristic of cuteness, conveying empathy, affection. This smoothness aspect is also expressed in color consistency, with light and neutral tones, which delivers a sort of lightness to the criticism, that is, it manifests itself in the discursive context without an aggressive bias. All these meanings characterize the transference, quoted by van Leeuwen (2005), showing that way the multimodal metaphors.

While not being hostile, the strategy of placing babies as alleged authors of the note makes the criticism manifest clear, since it is possible to infer the question: the opinion of babies on more complex issues has a scientific basis, can you accept it passively?

The criticism raised by this meme addresses a controversial issue today, as anti-vaccination movements have been growing in various parts of the world, which has generated different points of view. On the one hand, those in favor of the movement against vaccination, for various reasons, such as: side effects (because they believe that immunization can lead to permanent disability for the child); syringe contamination (for them there is no guarantee for the use of disposable materials); lack of belief in the effectiveness of vaccination; the association of vaccination with autism; lack of trust in the pharmaceutical industry, among others, listed on different websites and in different media, such as WhatsApp, Facebook, Instagram. On the other hand, there are health agencies, health professionals, the pharmaceutical industry and several citizens who defend immunization, anchored in other arguments: disease prevention; belief that lack of vaccination may allow the return of eradicated diseases; personal and collective protection; reduction of high costs for 
disease treatment; benefits of immunization for the protection of future generations, among others, found on various websites, scientific articles and in the media in general.

Furthermore, this meme reinforces that "memes contribute not only to generating humor but also to recording human thinking through social criticism" (CANI, 2019, p. 263). Thus, we emphasize that memes are important instruments for taking positions. Through them, it is possible to address different issues, such as: politics, economics, racial discrimination, religion, violence, among others, and define an opinion about them. As argued by Rojo (2012, p. 30), this aspect meets critical literacies "that seek to interpret the social and cultural contexts of circulation and production of these designs and statements. All this aiming, as an ultimate instance, to the production of a transformed practice $[\ldots]^{\prime \prime}$. 9

\section{Conclusion}

By proposing a discussion around the notion of texture as a synesthetic semiotic resource, we seek to address the possibilities of meaning production that it brings to visual and tactile surfaces. Our discussions focus on the meme genre in which resources are articulated in the construction of complex signs so that we produce meanings in an integrated way, in other words, in a multimodal set.

Besides seeing characteristics and functions of the meme as a text of cyberculture, we understand that semiotic work with this genre enhances the agency of subjects through the choice and selection of semiotic resources to materialize meanings. We observe that the choice of each mode and its affordances respectively is guided by the producer's interest. Thus, the sign reflects the interest of its producer in a process of metaphorical construction to get, at a given moment, its communicative purposes. Thus, the selection criteria are defined from metaphorical associations, in other words, experiential associations.

If we assume that our interactions are metaphorical, mediated by signs that are created at each interaction, in turn, motivated by the

\footnotetext{
${ }^{9}$ Our translation of: "que buscam interpretar os contextos sociais e culturais de circulação e produção desses designs e enunciados. Tudo isso visando, como instância última, à produção de uma prática transformada [...]” (ROJO, 2012, p. 30).
} 
interest of its producer, it is necessary to observe the semiotic work we do in choosing each mode besides understanding the work carried out by the representation and production technologies. Memes reveal how these associations weave texts and provide, in the words of Djonov and van Leeuwen (2011), synesthetic interaction of tactile and visual characteristics.

The semiotic work involved in the instantiation of memes shifts the reader into a meaning making process in which he/she needs to interact, negotiate, refute and so on. The articulation of these modes in memes is largely aimed at (re) contextualizing texts by provoking irony, humor, satire etc. thus transgressing the fixed and arbitrary character of the sign, (re) placing it in the ongoing process of creation to register the interest of a cognitively reflecting / dialoguing subject in a place in the physical, social, historical, cultural, conceptual world.

We shifted our focus away from describing meanings of visual communication to potential meanings of people, places, and things represented, and came to describe them in terms of combinations of abstract qualities, thus leaving the lexical logic to grammar logic, which allows us to construct a multitude of sign-complex with a toolbox composed of a restricted set of lexical options and grammatical operations. In short, this parallel, from the logic of the lexicon to the logic of grammar, reinforces the value of studying the text from a semiotic perspective.

As we reflect on how the qualities and aspects of tactile and visual textures that emerge from memes' multimodal metaphors, we realize that a singular statement 'é verdade esse bilhete' - this message is true - can turn into multiple meanings that imply a collectivity. Moreover, in order to understand the discourse(s), which may be inferred from texts, one must understand, behind a linguistic bias, the various semioses, semantic, pragmatic aspects raised by all forms of communication.

\section{Authorship Statement}

This paper developed by the three authors, members of the Brazilian research group in Multimodality, Reading and Text-GEMULTE, funded by the National Council for Scientific and Technological Development (CNPq). Data collection was performed by the third author. The authors selected the corpus and designed the analysis in the article. All authors collaborated on interpreting results, writing and revising the paper. 


\section{References}

BAKHTIN, M [Volochinov]. Marxismo e filosofia da linguagem. Tradução de Michel Lahud e Yara Frateschi Vieira. 12. ed. São Paulo: Hucitec, 2006a.

BAKHTIN. M. Estética da criação verbal. Trad. Paulo Bezerra. 4 ed. São Paulo: Martins Fontes, 2006b.

BEAUGRANDE, R. New Foundations for a Science of Text and Discourse: Cognition, Communication and Freedom of Access to Knowledge and Society. New Jersey: Ablex Publishing Corporation, 1997.

BRASIL. Parâmetros Curriculares Nacionais (Ensino Médio). Linguagens, Códigos e Tecnologias. Brasília: MEC, 2000.

BRUNO, A. R. Cultura digital e educação aberta: as curadorias digitais como inter e intrafaces do ensino híbrido. Trabalho e Educação, Belo Horizonte, v. 28. n. 1, p. 115-126, 2019. Available at: https://periodicos. ufmg.br/index.php/trabedu/article/view/12492/9923. Retrieved on: April $27^{\text {th }}, 2019$.

CANI, J. B. Multimodalidade e efeitos de sentido no gênero meme. Periferia, Rio de Janeiro, v. 11, n. 2, p. 242-267, 2019. Available at: https://www.e-publicacoes.uerj.br/index.php/periferia/article/ viewFile/36955/29635. Retrieved on: September $7^{\text {th }}$, 2019. DOI: https:// doi.org/10.12957/periferia.2019.36955

COLLOW, J. Literacy and the visual. English Teaching: Practice and Critique, [S.l.], v. 4, n. 1, p. 6-19, 2005.

COPE, B.; KALANTZIS, M. A grammar of multimodality. International Journal of Learning, [S.l.], v. 16, n. 2, p. 361-425, 2009. DOI: https://doi. org/10.18848/1447-9494/CGP/v16i02/46137

DJONOV E.; VAN LEEUWEN. The Semiotics of Texture: From Tactile to Visual. Sage Publications, [S.l.], v. 10, n. 4, p. 541-564, 2011. DOI: https://doi.org/10.1177/1470357211415786

FREIRE, P. Pedagogia do oprimido. São Paulo: Paz e Terra, 1993.

HALLIDAY, M. A. K. An Introduction to Functional Grammar. $2^{\text {nd }}$ Edition. London: Edward Arnold, 1994. 
HALLIDAY, M. A. K.; HASAN, R. (org). Language, Context and Text: Aspects of Language in a Social-Semiotic Perspective. 2. ed. Oxford: OUP, 2002.

HODGE, R.; KRESS, G. Social Semiotics. New York: Cornell University Press, 1988.

KRESS, G. Against arbitrariness: the social production of the sign as a foundational issue in critical discourse analysis. Discourse \& Society, London, v. 4, n. 2, p. 169-191, 1993. DOI: https://doi. org/10.1177/0957926593004002003

KRESS, G. Before Writing. London: Routledge, 1997.

KRESS, G. English for an Era of Instability: Aesthetics, Ethics, Creativity and "Design". English in Australia, Melbourne, v. 134, p. 15-23, 2002.

KRESS, G. Multimodality: A Social Semiotic Approach to Contemporary Communication. London: Routledge, 2010. DOI: https://doi. org/10.4324/9780203970034

KRESS, G. Semiotic Work: Applied Linguistics and Social a Semiotic Account of Multimodality. AILA Review, Siegen, DE, v. 28, p. 49-71, 2015. DOI: https://doi.org/10.1075/aila.28.03kre. Available at: https:// benjamins.com/catalog/aila.28.03kre. Retrieved on: April 25 th 2019.

KRESS, G.; VAN LEEUWEN, T. Multimodal Discourse: The Modes and Media of Contemporary Communication. London: Arnold, 2001.

LAKOFF, G.; JOHNSON, M. Metaphors We Live By. Chicago: The University of Chicago, Press, 1980.

LÉVY, P. O que é cibercultura. São Paulo: Editora 34, 1999.

MACHIN, D. Introduction to Multimodal Analysis. London: Hodder Education, 2007.

MARCUSCHI, L. A. Produção textual, análise de gênero e compreensão. São Paulo: Parábola Editorial, 2008.

ROJO, R. Pedagogia dos multiletramentos: diversidade cultural e de linguagens na escola. In: ROJO, R.; MOURA, E (org). Multiletramentos na escola. São Paulo: Parábola Editorial, 2012. p.11-31.

VAN LEEUWEN, T. Introducing Social Semiotics. London: Routledge, 2005. DOI: https://doi.org/10.4324/9780203647028 